living - may have to be developed and applied fast in the political arena if wo are to secure a society that will no more turn the fruits of natural science to anarchistic, irrational uses.

By misrepresenting current criticism of the misuses of i.echnology as a criticism of the scientifie enterprise, and by flippantly dismissing thoughtful warnings about the mischief to which now technologies may soon be put in our socicty, you are doing a disservice to the very cause of scientific progress and its financial support which they wish to uphold.

Yours faithfully,

S. E. LURIA

Massachusetts Institute of Technology,

Cambridge, Massachusetts.

The lcading article referred to dealt only in passing with the lettor from Dr Shapiro and his colleaguesEditor, Nature.

\section{Secondary Amines in Cooking}

Sir,-No doubt those food chemists working on the nitrosamine problem will want to comment on the Lijinsky and Epstein paper (Nature, 225, 21; 1970). My own observations are that, in spite of the general excellence of this essay, it has the element of scariness to which you draw timely attention in "How to Ban Chernicals without Scaring People" (Nature, 225, 3; 1970). I am ooncerned, in partieular, with the paragraphs based on the hypothesis that the cooking of food possibly affords a series of secondary amines which then proceed to be converted by nitrito present in the stomach into carcinogenic materials. More specifically, "Pyrolysis of protein and cooking of protein food might produce freo amino-acids such as proline, arginine and hydroxyproline". If this theory required testing, then the most useful protein to evaluate the validity would be collagen, particularly because proline and hydroxyproline are scantily represented in other protein sources associated with food. The imino and amino-acid content of a typical bovine collagen would include proline (14 per cent), hydroxyproline (14 per cent) and arginine (8 por cent) which, on the Lijinsky and Epstein hypothesis, could reprosent an enormous toxic danger in producing these imino and amino-acids in the free form for potential reaction with nitrite. The cooking of collagen is a regular rescarch procedure in these laboratories, employed to melt out golatine, and temporatures between $60^{\circ}$ and $100^{\circ} \mathrm{C}$ are used. Although we have frequently had cause to look for free amino-acids in extracts of collagen, there has never been any sign of proline, hydroxyproline or arginine, nor have they appeared as small peptides. This is not surprising. Different pairs of amino-acids take part in peptide bonds resulting in a variety of thermal stabilities. Those bonds with the highest labile character are those of Gly.Gly (ref. 1) while peptides containing proline seem to be unusually stable ${ }^{2}$. In the protein situation it is likely that extra stability will occur as a function of the position of dipeptide unit in the overall sequence. It invariably requires the drastic conditions of strong acids or bases at high temperatures to reduce collagen to peptide proportions, and even here free proline, hydroxyproline and arginine are unlikely, although ultimately the dipeptides Gly.Pro (ref. 3) and Hyp.Gly (ref. 4) become evident in acid hydrolysates. This is not to deny a possibility that cooking might promote the reaction of secondary amines with in situ nitrite to the nitroso derivative, but rather to distrust the suggestion that the secondary amines could be proline, hydroxy. proline or arginine in the free state. Again, although the chemistry of the route to piperidine and pyrolidino from the diamines, cadaverine and putrescine is not in dispute, it seems unlikely that a consistent ingestion by humans, particularly of decayed meat and fish, would make these a practical suggestion as a secondary amine source.

\section{Yours faithfully,}

\section{A. Courts}

Gelatine and Glue Research Association, Birmingham 12.

1 Synge, R. L. M., Bischem. J., 39, 351 (1945).

${ }^{2}$ Consden, R., Gordon, A. H., Martin, A. J. P., and Synge, R. L. M., Biochem. I., 41, $596(1947)$.

${ }^{3}$ Heyns, K., Anders, G., and Becker, E., Z. Physiol. Chem., 287, 120 (1951). 1 Schroeder, W. A., Kay, L. M., I. Gette, J., Honnen, L., and Green, F. C.,
J. Amer. Chem. Soc., 76, 3556 (1954).

\section{Palaeontological Data}

SIR,-A recent issue of Nature $(\mathbf{2 2 4}, 636 ; \mathbf{1 9 6 9 )}$ contained a report of a plan for a proposed archive of palaeontolog. ical data in Great Britain. In this report mention was made of a central file of palaeontologieal data based on the New Zealand Geologieal Survey. This national file, established in 1951, is administered through regional masterfiles held at the geology departments of four universities and scven offices of the New Zealand Geological Survey1,2. The file is the result of outstanding collaboration between institutions and geologists in New Zealand, and is a valuable source of stratigrapbic and palaeontological data. The present content of the file is summarized by Speden ${ }^{3}$.

At its annual general meeting held in Dunedin on December 1, 1969, the (Xeological Society of New Zealand accepted recommendations to assume responsibility for the New Zealand Fossil Record File and to encourage computerization of the filc $^{2}$, and a standing committee to supervise the file has been established. A pilot project on computerization of the file has been in progress since $1965^{4}$ and is now being developed at the national lovel. Yours faithfully,

NZ Fossil Record File,

\section{G. SPEDEN}

NZ Geological Survey,

PO Box 30368, Lower Hutt, New Zealand.

${ }^{1}$ Fleming, C. A., Geol. Soc. NZ Newsletter, 5, 27 (1958).

"Sperien, I. G., Geol. Stoc. NZ Newstetter, 27, 25:(1969).

${ }^{3}$ Speden, I. G., Geol. Soc. NZ Newsletter, 27, 31 (1969).

4 Scott, G. H., NZ Geol. Survey Report (July 1967).

\section{University News}

Dr J. V. Armitage, at present senior lecturer in mathematics at King's College, London, has been appointed to the Chair of Mathematical Education at the University of Nottingham. Dr Armitage will also act as director of the Shell Centre for Mathematical Education.

Mr Neil Spoonley has been appointed director of the University of London Computer Centre.

Dr Brian D. Nellist has been appointed as the first director of the Industrial Centre for Design and Manufacturing Engineering, University of Salford.

\section{Appointments}

Mr Donald Rowley, executive director of the British Aireraft Corporation's Electronic and Space Systems Group, has been appointed chairman of the National Industrial Space Committee.

Three new mombers have been appointed to the Social Science Research Council: Professor Harry Kay (University of Sheffield), Professor N. Lichfield (University College London) and Professor L. W. Martin (King's College London). 